\title{
An analysis of underlying constructs affecting the job satisfaction amongst accountants
}

\section{Dang Huy Nguyen ${ }^{a^{*}}$}

\begin{tabular}{|c|c|}
\hline C H R O N I C L E & A B S T R A C T \\
\hline $\begin{array}{l}\text { Article history: } \\
\text { Received: September } 152019 \\
\text { Received in revised format: Sep- } \\
\text { tember } 282019 \\
\text { Accepted: November } 2,2019 \\
\text { Available online: } \\
\text { November 2, } 2019 \\
\text { Keywords: } \\
\text { Job satisfaction } \\
\text { Factor } \\
\text { Accounting service firms } \\
\text { Accountants }\end{array}$ & $\begin{array}{l}\text { The study aims to identify and measure factors affecting the job satisfaction amongst accountants in accounting } \\
\text { service firms in Hanoi. Based on literature review and the results of some interviews, a total of } 200 \text { question- } \\
\text { naires were sent to research participants for recollection within } 1 \text { month; } 145 \text { of them met standard and were } \\
\text { subject to analysis. The results of Exploratory Factor Analysis (EFA) and Multiple Regression Analysis (MRA) } \\
\text { identified } 5 \text { main factors affecting job satisfaction amongst accountants: (i) salaries, (ii) welfare regimes; (iii) } \\
\text { Recognized achievements and rewards, (iv) working conditions and (v) training and promotion. On this basis, } \\
\text { some recommendations have been improved the job satisfaction of the accountant in the accounting service } \\
\text { firms in Hanoi. }\end{array}$ \\
\hline
\end{tabular}

\section{Introduction}

Job satisfaction is a state in which employees are clearly oriented towards their organization's work (Vroom, 1964) or truly enjoying their work (Locke, 1976). According to Luddy (2005), job satisfaction is an emotional response to various aspects of an employee's job. Job satisfaction has a positive effect on job performance (Spector, 2007), job satisfaction has a positive effect on organizational loyalty (Luddy, 2005). Studying job satisfaction of employees plays a very important role in human resource management and is applied in practice to improve personal life as well as the effectiveness of the organization (Dang, 2016). Accounting services in Vietnam have continuously improved in service quality and have affirmed its position in the national economy. Accounting services help customers catch up with and understand the state's guidelines and policies on regional and international economic integration, financial and economic management activities, accounting and taxes and business risks. Accounting services detect weaknesses and errors in financial management as well as in accounting and internal control of the business. The services provide valuable advice to help enterprises improve and complete the internal control system and accounting system, etc. (Mai, 2013). However, in some accounting service firms, the management and operations are still inadequate and the professionalism is limited; some accountants take charges in multiple tasks, so they are not dedicated to the work (Mai, 2013). Therefore, accounting service firms need solutions to improve professionalism and accountants need to more focus on the job. Improving the job satisfaction of accountants is one of the solutions that are either urgent or long-term. Because through the satisfaction of the accountants, the leadership of the accounting service firm will recognize the unsuitable factors in order to make reasonable adjustments, thereby increasing the efficiency of the work of accountants. The purpose of this study is to identify factors that affect the job satisfaction of accountants in accounting service firms in Hanoi, to build models and scales of those factors, to measure the influence of each factor on the job satisfaction of the accountant and propose recommendations to improve the job satisfaction of the accountant in the accounting service firms in Hanoi.

\footnotetext{
* Corresponding author. Tel.: +84912693996

E-mail address: danghuykdcn@yahoo.com (D. H. Nguyen) 


\section{Literature review}

Studies around the world and in Vietnam focus on factors that affect job satisfaction including: (i) salary, bonus and welfare regimes; (ii) recognized achievements and rewards, (iii) working conditions and (iv) training and promotion.

\section{Salary and welfare}

Income and welfare are the most important factors for employees (Simons \& Enz, 1995). Oshagbemi (2000) points out that there is a relationship between wages and job satisfaction with statistical analysis. Marc (2007) affirms that economic benefits, particularly salaries, are the most important factor of private - sector employees. Salaries and bonuses are always essential factors to attract workers. Artz (2008) argues that welfare plays an important role in determining job satisfaction. Salary is the amount of money that workers receive when they work. This money will be used to pay for living cost, compensate and reproduce the labor force as well as ensure their families' lives. In developing countries such as Vietnam, wages or income are still an important factor affecting job satisfaction (Tran \& Nguyen, 2011; Nguyen, 2014; Nguyen \& Luu, 2017; Nguyen \& Pham, 2017, Hoang, 2018).

\section{Working conditions}

Good working conditions include a safe environment, adequate tools to work, reasonable working hours, happy workplace, labor hygiene, risk-free, necessary equipment for and well-organized labor protection. Good working conditions will positively impact workers' satisfaction (Kovach, 1987; Nguyen, 2014; Nguyen \& Luu, 2017; Nguyen \& Pham, 2017; Hoang, 2018).

\section{Training and promotion opportunities}

According to Stanton and Crossleey (2000), promotions are related to employees' perceptions of training opportunities, personal capacity development and promotion opportunities within the organization. Employers who create various opportunities for development and promotion will have a lower turnover rate of employees compared with others because the lack of training and promotion opportunities is the main reason leading to qualified employees to leave the company (Allen et al., 2003). Luddy (2005) suggested that promotion opportunities are closely related to the job satisfaction of workers. Tran and Nguyen (2011), Nguyen (2014), Nguyen and Luu (2017), Nguyen and Pham (2017), Hoang (2018) showed the opportunity for promotion has a positive impact on job satisfaction. Tran (2005) measures job satisfaction in Vietnamese conditions and shows that training and advancement factors are one of the 7 factors that affect employee's job satisfaction.

\section{Recognized achievements and rewards}

Through interviews with HDbank staff in Ho Chi Minh City, Nguyen and Pham (2017) added the factor "Recognized achievements and rewards" to build the research model. There are 8 factors affecting the job satisfaction of bank staff, this factor is also consistent with the current situation to motivate employees to try to work. The research results show that the factors of recognition of achievements and rewards have positive effects on the job satisfaction of bank employees.

The above studies have identified factors that influence the job satisfaction of employees. However, some studies only use qualitative research methods. Besides, no research has been conducted so far to analyze and measure the impact of factors influencing the job satisfaction amongst accountants in accounting service firms in Hanoi. By inheriting those previous studies, this research by selecting appropriate research methods continues to expand and develop a new model to analyze, evaluate and measure the influence of factors on the job satisfaction amongst accountants in accounting service firms in Hanoi.

\section{Theories involving research topic}

\subsection{Maslow's needs tower theory}

Maslow (1943) found that human needs are arranged in a hierarchical order and can be divided into two main groups: lowend needs and high-end needs. Low-level needs include basic needs and safety needs. High-level needs include: social needs, needs of respect, needs to express themselves. Maslow believes that higher-level needs will not appear unless these basic needs are met and these basic needs will tame, urge and prompt someone to act on demand if this basic has not been achieved. According to Maslow, once the low-end needs have been satisfied, the high-end needs will become the driving force for all human behavior. Unmet need for lower levels will often cause discontent in higher-order needs; therefore, lower - level needs must often be satisfied before a person can move up the higher hierarchy of needs. Applying the theory to this research: This study is based on Maslow's demand pyramid theory (1943), to analyze and evaluate the dependent variables "job satisfaction of accountant" and independent variables (i) Salarys, (ii) welfare regimes, (iii) recognized achievements and rewards, (iv) working conditions and (v) training and promotion.

\subsection{Herberg's two-factor theory}

Henzberg (1959) conducted a study and identified two groups of factors: 
(i), The Elementary Group maintains a normal working motivation including issues such as corporate policies and governance, oversight, working conditions, and interpersonal relationships employees, salaries, positions, occupational safety and personal life. If these factors are not satisfied, it will lead to job dissatisfaction.

(ii), The second group of factors leads to work motivation. These factors are: achievement, recognition, challenging work, recognition of progress and maturity in the job. These factors provide job satisfaction if it is met. He also thinks that these factors will motivate internal motivation of workers. Applying this research: Management boards and leaders at all levels of accounting service firms need to understand the needs of accountants in their jobs, specify and divide them into groups for accountants. This helps managers make decisions more easily in their work such as decisions about salaries, Welfare, recognition of achievements and rewards, working conditions (related to independent variables in the research model).

\subsection{Theory of promotion according to expectations}

Vroom (1964) proposed and developed this theory. This theory is based on the relationship between an individual's effort working outcome - remuneration or achievement. These relationships are expressed (i) The relationship between personal effort and working outcome; (ii) The relationship between job performance and expected benefits. This expected benefit could be earnings, additional paychecks, promotion opportunities, or any other reward that satisfies the employee's personal goals. Applying the theory to this research: This theory suggests that managers in accounting service firms need to make accountants understand the direct relationship between effort - achievement, achievement and results or rewards as well as need to create an appeal of results / rewards to accountants. As such, this theory deals with independent variables of salaries, Welfare, recognition of performance and reward, training and promotion.

\section{Research Methodology}

In order to achieve the objectives of this paper, we based on the theory of previous studies and the results of qualitative research through expert interviews and model analysis. On the other hand, we combined with the inductive method to verify, based on qualitative research results, to adjust and add observation variables to the questionnaire for conducting quantitative research. Inheriting the results of research by Simons and Enz (1995), Oshagbemi (2000), Marc (2007), Artz (2008), Tran and Nguyen (2011), Nguyen (2014), Nguyen and Luu (2017), Nguyen and Pham (2017), Hoang (2018), Kovac (1987), Stanton and Crossleey (2000), Allen et al. (2003), Luddy (2005), Maslow (1943), Henzberg (1959) and Vroom (1964) and using qualitative research approach through interviews with experts to perform quantitative research, we identify five determinants that affect the job satisfaction amongst accountants, i.e. Salaries (S), Welfare (W), Recognized achievements and rewards (RAR), Working conditions (WCs), Training and promotion (TP). We interviewed 5 lecturers with extensive experiences in accounting in accounting service firms of the National Economics University and University of Labor and Social Affairs and 4 experts working as chief accountants in accounting service firms. The contents of the interviews based on the draft scale includes 5 factors and 26 attributes (indicators). The results showed that, experts identified 5 factors and attributes (indicators) are appropriate, do not add any more factors. Thus, this study has the draft scale which includes 5 factors and 26 attributes (indicators) in Table 1 as follows,

Table 1

The attributes (indicators) of factors influencing on the job satisfaction amongst accountants

\begin{tabular}{|c|c|}
\hline Code & Scale \\
\hline \multicolumn{2}{|l|}{ Salaries (S) } \\
\hline S1 & Salary is commensurate with the nature of the work and the results of the work \\
\hline S2 & Basic salary is suitable for the job \\
\hline S3 & Fair salary among employees \\
\hline S4 & Reasonable allowances \\
\hline S5 & Salaries are on par with other companies' businesses \\
\hline S6 & Salaries are sufficient to meet the basic needs of life \\
\hline S7 & Salaries are evaluated to increase annually \\
\hline \multicolumn{2}{|c|}{ Welfare $(\mathbf{W})$} \\
\hline W1 & Welfare policy is clear \\
\hline W2 & Welfare policy shows considerate care for workers \\
\hline W3 & The welfare regime in my company is fair \\
\hline W4 & The welfare regime at the company is similar to other companies in the same area \\
\hline W5 & The company has a reasonable leave and holiday regime \\
\hline \multicolumn{2}{|c|}{ Recognized achievements and rewards (RAR) } \\
\hline RAR1 & The company recognizes the accountants' contribution to the development of the company \\
\hline RAR2 & The company has a policy of reward based on work results \\
\hline RAR3 & Reward policies are timely, clear, fair and public \\
\hline RAR4 & The company consistently implements and completes incentive policies and recognition of achievements \\
\hline \multicolumn{2}{|c|}{ Working conditions (WCs) } \\
\hline WCs1 & Fully equipped with necessary tools and facilities \\
\hline WCs2 & The workplace has good facilities, is comfortable, clean and ensures safety \\
\hline WCs3 & Reasonable working hours \\
\hline WCs4 & No worry to lose job \\
\hline \multicolumn{2}{|c|}{ Training and promotion (TP) } \\
\hline TP1 & Equal promotion opportunities for accountants \\
\hline TP2 & There are many promotion opportunities for accountants \\
\hline TP3 & The company plans to train, develop staff and regularly organize training to meet work needs \\
\hline TP4 & The accounting profession association in Vietnam regularly organizes training to meet its work needs \\
\hline TP5 & Participate in training courses to improve qualifications and work effectively \\
\hline TP6 & The company's current training programs and accounting professional associations in Vietnam are highly effective \\
\hline
\end{tabular}


After having the draft scale table with 5 factors and 26 attributes, we designed a draft questionnaire. We then tested 33 accountants working at accounting service firms in Hanoi, through convenient sampling methods to establish the model and official scales. The results show that all factors and attributes are reliable. However, in the Welfare factor, the attribute "The company has a reasonable leave and holiday regime" and in the working conditions factor the attribute "no worry to lose job" have Corrected Item - Total Correlation $<0.3$; so they are disqualified. After that, we replayed the factor "Welfare" with the remaining 4 attributes, the working conditions factor with the remaining 3 attributes and the results show that Cronbach's Alpha $>0.6$ and Corrected Item - Total Correlation $>0.3$, therefore, it meets the demand. We use SPSS 23 for analysis to determine reliability through Cronbach's Alpha. The final result is 5 factors and 24 attributes that gain reliability. Thus, the official model and scale of this study includes 5 factors and 24 observation variables with a 5-point Likert scale. Independent variables are measured from 1 "without effect" to 5 "strongly". According to Hair et al. (1998): The research sample must be at least 5 times the total number of indicators in the scales. The questionnaire of this study includes 24 indicators, therefore, the minimum sample size to achieve are $5 \times 24=120$ observations. We sent 200 questionnaires directly to accountants in accounting service firms and received the feedback of 175. Time to complete is one month. After checking the information on the returned questionnaires, there were 145 questionnaires with full information for data entry and analysis, the size of this sample was consistent with study of Hair et al. (1998). From the above analysis, the research model is designed as follows:

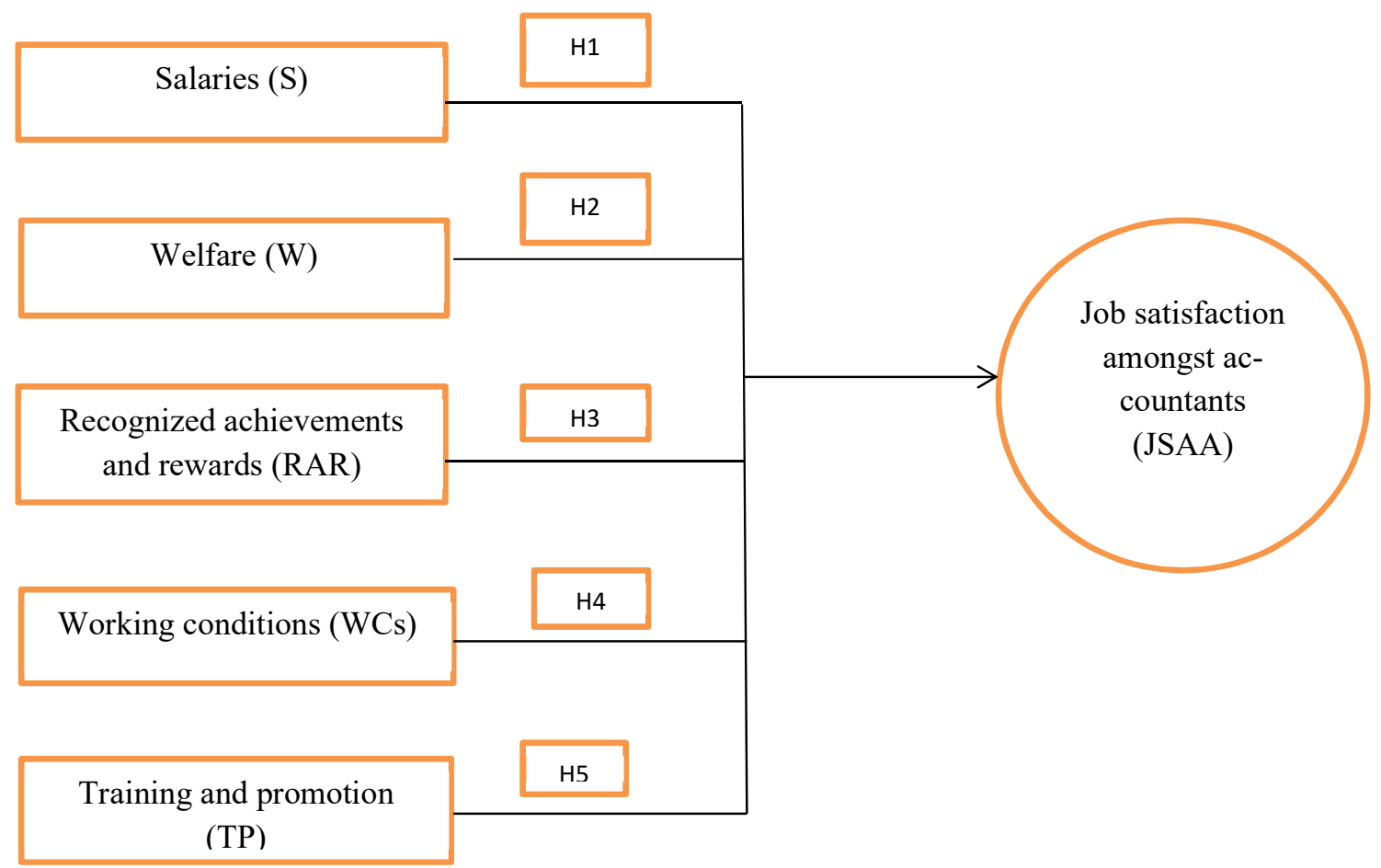

Fig. 1. Research model

Dependent variable: Job satisfaction amongst accountants (JSAA)

Independent variables: Salaries (S), Welfare (W), Recognized achievements and rewards (RAR), Working conditions (WCs), Training and promotion (TP).

\section{Hypothesis}

H1: Salaries have a positive influence on the job satisfaction amongst accountant.

H2: Welfare have a positive influence on the job satisfaction amongst accountant.

H3: Recognized achievements and rewards have a positive influence on the job satisfaction amongst accountant.

H4: Working conditions have a positive influence on the job satisfaction amongst accountant.

H5: Training and Promotion have a positive influence on the job satisfaction amongst accountant.

\section{Research results}

\subsection{Descriptive Statistics}

Information of data collected is shown in Table 2. Data in Table 2 show that among the 145 respondents, $22.1 \%$ of the participants were male while the remaining 113 were female, representing for $77.9 \%$. Of these, 35 of them are less 27 years old, accounting for $24.1 \% ; 31$ of them are over 35 years old, accounting for $21.4 \%$; and $54.5 \%$ of the participants are from 27 to 35 years old. Among the 145 respondents, of which 8 with college degrees, accounted for 5.5\%; 131 with university degrees, 
accounted for $90.3 \%$, MA degrees accounted for $4.1 \%$. Besides, accounting human resources for less than 5 years is 35 , accounted for $24.1 \%$, Over 10 years accounted for $24.1 \%$, while the remaining 75 , were from 5 to 10 years.

Table 2

Respondents by gender, age, education level and work experience

\begin{tabular}{|c|c|c|c|}
\hline & Frequency & Percent & Cumulative Percent \\
\hline \multicolumn{4}{|l|}{ Gender } \\
\hline Male & 32 & 22.1 & 22.1 \\
\hline Female & 113 & 77.9 & 100.0 \\
\hline \multicolumn{4}{|l|}{ Age } \\
\hline From 27 to 35 years old & 79 & 54.5 & 54.5 \\
\hline Less 27 years old & 35 & 24.1 & 78.6 \\
\hline Over 35 years old & 31 & 21.4 & 100.0 \\
\hline \multicolumn{4}{|l|}{ Education level } \\
\hline College & 8 & 5.5 & 5.5 \\
\hline University & 131 & 90.3 & 95.9 \\
\hline Master's (MA) & 6 & 4.1 & 100.0 \\
\hline \multicolumn{4}{|l|}{ Work experience } \\
\hline From 5 to 10 years & 75 & 51.7 & 51.7 \\
\hline Less 5 years & 35 & 24.1 & 75.9 \\
\hline Over 10 years & 35 & 24.1 & 100.0 \\
\hline Total & 145 & 100.0 & \\
\hline
\end{tabular}

Quality scale analysis result

By using scale analysis, it can eliminate inconsonant variables and reduce errors in the research model. Therefore, only variables which have total correlation coefficients (Corrected Item - Total Correlation) greater than 0.3 and Cronbach's Alpha coefficients equal or greater than 0.6 are accepted (Hoang \& Nguyen, 2008). By analyzing Cronbach's Alpha analysis of determinants have an influence on the job satisfaction amongst accountant ( 5 determinants with 24 observed variables), the result is presented in Table 3 .

Table 3

Results of analysis of Determinants Confidence of Scales in the Model

\begin{tabular}{llcc}
\hline \multicolumn{1}{c}{ Determinants } & $\mathrm{n}$ & Cronbach's Alpha & Corrected Item-Total Correlation \\
\hline Salaries (S) & 7 & 0.863 & 0.583 \\
Welfare (W) & 4 & 0.822 & 0.595 \\
Recognized achievements and rewards (RAR) & 4 & 0.680 & 0.381 \\
Working conditions (WCs) & 3 & 0.746 & 0.423 \\
Training and promotion (TP) & 6 & 0.836 & 0.362 \\
\hline
\end{tabular}

The result shows that, all Cronbach's Alpha coefficients of population are above 0.6; all Corrected Item - Total Correlation of observed variables are above 0.3 . Thus, all variables of research model are suitable for next analyses (Hair et al., 2006).

Exploratory Factor Analysis

Exploratory Factor Analysis (EFA) was conducted through Component Analysis and Varimax and the results has yield 24 attributes of independent variable.

\section{Table 4}

KMO and Bartlett's Test

\begin{tabular}{lcl}
\hline Kaiser-Meyer-Olkin Measure of Sampling Adequacy. & .831 \\
Bartlett's Test of Sphericity & Approx. Chi-Square & $1,848.455$ \\
& Df & 276 \\
& Sig. & 0.000 \\
\hline
\end{tabular}

The results of factor analysis in Table 4 show that $0.5<\mathrm{KMO}=0.831<1$. Bartlett's testimony shows sig. $=0.000<0.05$, which means variables in the whole are interrelated. After implementing the rotation matrix, 5 determinants with factor load factor are greater than 0.5 ; Eigenvalues are greater than 1 and the variance explained is $64.500 \%$. These statistics demonstrate that research data analysis for factor discovery is appropriate. Through the quality assurance of the scale and the test of the EFA model, we have identified 5 determinants influencing the job satisfaction amongst accountant.

\section{Regression Model Analysis Result}

Based on adjusted model after the exploratory factor analysis, we use a multiple regression model as follows:

$$
\mathrm{JSAA}=\alpha+\beta_{1} \mathrm{~S}+\beta_{2} \mathrm{~W}+\beta_{3} \mathrm{RAR}+\beta_{4} \mathrm{WCs}+\beta_{5} \mathrm{TP}
$$

Multicollinearity testing 
All variance inflation factor (VIF) of independent variables are under 2, so multicollinearity of model is low (Hoang \& Nguyen, 2008). Therefore, this regression model does not have any violation of the CLRM basic assumption. Durbin - Watson statistics which is used to test the autocorrelation of residuals presents the model does not violate when using multiple regression method because Durbin - Watson value is 2.129 (in the interval of 1 and 3). In other words, the model has reported no autocorrelation between residuals (Hoang \& Nguyen, 2008).

Table 5

Model Summary

\begin{tabular}{|c|c|c|c|c|c|}
\hline Model & $\mathrm{R}$ & R Square & Adjusted R Square & Std. Error of the Estimate & Durbin-Watson \\
\hline 1 & $.658^{\mathrm{a}}$ & .567 & .533 & .67999 & 2.129 \\
\hline
\end{tabular}

a. Predictors (Constant): TP, WCs, S, W, RAR

b. Dependent Variable: JSAA

ANOVA testing result: Level of significant (Sig.) $=0.014$ implies that multiple regression model is suitable with data. Coefficient of $\mathrm{R}^{2}$ (R Square) $=0.533$, which means $53.3 \%$ of the total variation in the job satisfaction amongst accountant will be explained by the regression model.

Table 6

Anova $^{\mathrm{a}}$

\begin{tabular}{llcccc}
\hline \multicolumn{2}{l}{ Model } & Sum of Squares & Df & Mean Square \\
\hline 1 & Regression & & & Sig. \\
& Residual & 4.591 & 5 & 3.918 & $.014^{\mathrm{b}}$ \\
& Total & 64.271 & 139 & .462 & 1.986 \\
\hline
\end{tabular}

a. Dependent Variable: JSAA

b. Predictors: (Constant): TP, WCs, S, W, RAR

Table 7

Coefficients $^{\mathrm{a}}$

\begin{tabular}{|c|c|c|c|c|c|c|c|}
\hline \multirow[t]{2}{*}{ Model } & \multicolumn{2}{|c|}{$\begin{array}{l}\text { Unstandardized } \\
\text { Coefficients }\end{array}$} & \multirow{2}{*}{$\begin{array}{c}\begin{array}{c}\text { Standardized } \\
\text { Coefficients }\end{array} \\
\text { Beta }\end{array}$} & \multirow[t]{2}{*}{$\mathrm{T}$} & \multirow[t]{2}{*}{ Sig. } & \multicolumn{2}{|c|}{$\begin{array}{c}\text { Collinearity } \\
\text { Statistics }\end{array}$} \\
\hline & $\mathrm{B}$ & Std. Error & & & & Tolerance & VIF \\
\hline (Constant) & 4.072 & .553 & & 7.366 & .000 & & \\
\hline $\mathrm{S}$ & .494 & .123 & .551 & 1.569 & .019 & .727 & 1.376 \\
\hline W & .129 & .132 & .204 & 1.298 & .031 & .586 & 1.706 \\
\hline RAR & .459 & .146 & .532 & 1.485 & .030 & .455 & 1.899 \\
\hline WCs & .353 & .084 & .453 & 1.822 & .021 & .958 & 1.044 \\
\hline TP & .325 & .161 & .303 & 1.104 & .031 & .382 & 1.918 \\
\hline
\end{tabular}

a. Dependent Variable: JSAA

Research model result indicates that all independent variables Salaries (S), Welfare (W), Recognized achievements and rewards (RAR), Working conditions (WCs) and Training and Promotion (TP) are significant (because Sig. $<0.05)$ and influence on the job satisfaction amongst accountant. Determinants have influences on the job satisfaction amongst accountant and are presented in the following standardized regression model:

$$
\mathrm{JSAA}=0.551 \times \mathrm{S}+0.204 \times \mathrm{W}+0.532 \times \mathrm{RAR}+0.453 \times \mathrm{WCs}+0.303 \times \mathrm{TP}
$$

Thus, the order of influence of these factors are Salaries (S), Recognized achievements and rewards (RAR), Working conditions (WCs), Training and Promotion (TP), Welfare (W).

\section{Discussions}

Salaries of the accountants in accounting service firms

The correlation value indicates that for salary there is a positive relationship with job satisfaction $(\beta=0.551)$. Hence, it is of necessity for accounting service firms to take this factor into consideration, to analyze as well as to draw solutions for it. Since the main goal of almost every employee is to have money to take care of themselves and their families as well, and if wages can help them make ends meet, there is no reason why they are not satisfied with their current position and vice versa (Nguyen \& Pham, 2017). There is a fact that most of the accounting service firms still implement an employee hierarchy for payroll processing but not set up any policy to increase salary for outstanding employees who complete their job and always strive to have good performance. Normally, working time of human resources is calculated monthly, working 8 hours / day, 5.5 days / week. However, if in the accounting season or the time when firms work, the accountants will have to work overtime. Income from the average monthly salary of accounting human resources for less than 4.5 million VND accounted for $6.2 \%$; from 4.5 to 6.75 million, accounted for $4.1 \%$; from 6.75 to 10 million VND accounted for the highest percentage (67.6\%), the rest was over 10 million VND. Income from wages has a difference between job positions and work experience. In addition to salary over time, accountants receive a sales salary for completed service provision contracts. If the accountant introduces new customers to the company, the accountant will also receive a commission of $5 \%$ to $10 \%$ of the revenue from that customer (Do et al., 2019a). When the income level that the accounting human resources receive is commensurate with the merit and work that makes them comfortable and effective, it will attract the dedication and wisdom of the people. Therefore, enterprises' 
managers of accounting services firms need to pay more attention, contributing to the use of effective accounting human resources, as a competitive factor in the process of sustainable development (Do et al., 2019a).

\section{Recognized achievements and rewards in accounting service firms}

In the regression above, this factor has the coefficient of $\beta=0,532$, which indicates that reorganization and rewards have a fairly strong positive effect on job satisfaction. In other words, the more rewards and reorganization in accountants' dedication, the more they devote to their firms. Several accounting firms have developed a reward policy for employees. However, some conditions included in the policy seems to be difficult for accountants to achieve, thus, employees think that the reward policy is just an unrealistic goal that managers set for them in order to encourage staffs to keep moving on.

\section{Working conditions in accounting service firms}

This factor has a coefficient of $\beta=0.453$, which suggests that working conditions also have a significant influence on job satisfaction. However, in fact, some accounting service firms have not had appropriate measures on overtime hours for accountants, especially during the "financial statements period". In some accounting service firms, equipment and facilities used for accounting work have not been highly appreciated by employees. The reason lies in the fact that the repair process of broken computers, photocopiers or printers, etc. sometimes takes a long time. Besides, the company's IT department is quite unskilled or there is no independent IT department or no coordination among departments to support the workflow, thus leading to accountants' poor performance. Accounting accountants in accounting service firms in Hanoi often work concentrated in the company's office, both working independently and working in teams. In addition to working time at the company office, the teams also have to go on business trips or work at the customer's production and business locations (Do et al., 2019a).

\section{Training and promotion in accounting service firms}

This factor has a coefficient of $\beta=0.303$, which means that training and promotion of accountants have the four effects on job satisfaction. In some accounting service firms today, despite the fact that they often organize training programs for their employees, the result seems to be ineffective due to a number of reasons such as: Out of date documents, unreasonable training time, theoretical knowledge, etc. "Equal promotion opportunities for accountants" is currently quite feasible at accounting service firms because employees get the job by their ability and are evaluated on their performance and actual competence by company and colleagues. The results of that evaluation are used as a basis for the appointment of leadership positions.

\section{Welfare regimes in accounting service firms}

In order to find the relationship between job satisfaction and welfare policy in accounting firms, regression measure was utilized and we found that this factor has the least impact on accountants' job satisfaction among 5 factors $(\beta=0.204)$. As we mentioned above, the main goal of employees is remuneration they are offered, but not how many benefits they can gain in companies. Thus, they rarely pay attention to welfare policy in their workplaces. In the accountants' point of view, since the welfare policy in their company and that in the other accounting firms have not many differences, benefits that they receive are quite similar, regardless of working experience or working time at the company. Accounting service firms have facilitated and promoted cultural activities, sports, sightseeing, vacation and exchanges. However, the organization of those events is still occasional and the activities during each event are not opulent. Specifically: annual vacation activities, year-end ceremony and anniversary of founding the company are held once a year, while other activities such as cultural and artistic exchanges, sport competitions are not organized, or organized within a short period, thus not attractive enough for accountants (Do et al., 2019b).

\section{Recommendations}

Accounting service firms should review their reward policy for their employees; replace the difficult conditions that are out of accountants' abilities with the more appropriate ones. Accountants have the rights to raise their voices and take part in the process of establishing the reward policy. Accounting service firms need to acknowledge that immediate repairment for all broken equipment is really necessary in order not to affect the accountants' work process. The quantity and quality of information technology (IT) departments in accounting firms need to be improved and there should not be a discontinuity in coordination between IT department and accountants, which results in a timely and effective working process in a whole company. Accounting service firms should complete their overtime policy with actual capacity that their employees fulfill. Improving the effectiveness of training programs is one of the urgent and long-term plans to accounting service firms: Documents need updating, the time of training must be appropriate, lecturers should be well qualified and have enough hands-on experience to lead classes. Accounting service firms need to develop and implement a policy of early pay rise for accountants who continually fulfill their tasks and regularly create motivation to strive to complete the job effectively. The time to increase the salary before maturity can be 1 year, 9 months or 6 months depending on the results of successfully completing the task.

\section{References}

Allen, D. G., Shore, L. M., \& Griffeth, R. W. (2003). The role of perceived organizational support and supportive human resource practices in the turnover process. Journal of Management, 29(1), 99-118. 
Artz, B. (2008). The role of firm size and performance pay in determining employee job satisfaction brief: firm size, performance pay, and job satisfaction. Labour, 22(2), 315-343.

Dang, H.V. (2016). The determinants influencing the job satisfaction of worker in SMEs in Binh Dinh Province. Asia Pacific Economic Journal, 9, 63-66.

Do, D. T., Tran, B. M., Nguyen, T. N. L., Truong, D. D., \& Tran, M. D. (2019a). Determinants influencing the quality of accounting human resources: The case of Hanoi, Vietnam, 10th International conference socio - economic and environmental issues in development, 711-726.

Do, D.T., Nguyen, D.H., Nguyen, T.H., \& Vu, H.P., (2019b). Job satisfaction amongst accountants: The case of accounting service firms in Hanoi. Research Journal of Finance and Accounting, 10(18), 134-139.

Hair, J. F., Anderson, R. E., Tatham, R. L., \& Black, W. C. (1998). Multivariate data analysis. Englewood Cliff. New Jersey, USA, 5(3), 207-2019.

Hair, J. F., Black, W. C., Babin, B. J., Anderson, R. E., \& Tatham, R. L. (2006). Multivariate data analysis (Vol. 6).

Henzberg, F. (1959). The Motivation to Work. Harvard Business Review Classics, New York.

Hoang, K.O. (2018). Study on the factors affecting the job satisfaction of staff of Hanoi University of Internal Affairs. Journal of Human resources for Social Sciences, 9, 116-120.

Hoang, T., \& Nguyen, M. N. C. (2008). Analysis of research data with SPSS. Vietnam: Hong Duc Publishing House.

Kovach, K. A. (1987). What motivates employees? Workers and supervisors give different answers. Business Horizons, 30(5), 5865 .

Locke, E. A. (1976). The nature and causes of job satisfaction. Handbook of industrial and organizational psychology.

Luddy, N. (2005). Job satisfaction amongst employees at a public health institution in the Western Cape (Doctoral dissertation, University of the Western Cape).

Mai, T. H. M. (2013). Vietnam Accounting Services, limitations to overcome. Accounting and Auditing Journal, 13(1), 7-9.

Marc, B. (2007). Differences between private and public sector employees' psychological contracts. Journal of Public Administration Research and Theory, 17, 581-606.

Maslow, A. H. (1943). A theory of human motivation. Psychological Review, 50(4), 370.

Nguyen, B.M. (2014). Determinants influencing the job satisfaction of industrial hygiene worker in Hanoi. Journal of Science anh technology, 22, 73-79.

Nguyen, M.L \& Luu, T.V. (2017). Identifying factors affecting job satisfaction of workers working at construction sites located in District 2 - Ho Chi Minh City, Construction Journal, 6, 31-33.

Nguyen, V.T \& Pham, X.T. (2017). Employees satisfaction in HDBank Ho Chi Minh. Banking Technology Review, $135,102-113$.

Oshagbemi, T. (2000). Gender differences in the job satisfaction of university teachers. Women in Management review, 15(7), 331343.

Simon, D. H., \& DeVaro, J. (2006). Do the best companies to work for provide better customer satisfaction?. Managerial and decision economics, 27(8), 667-683.

Spector, P. E. (1997). Job satisfaction: Application, assessment, causes, and consequences (Vol. 3). Sage publications.

Stanton, J. M., \& Crossley, C. D. (2000). Electronic resources for the JDI and JIG. Bowling Green, OH: Bowling Green State University.

Tran, K.D. (2005). Measurement of job satisfaction in Vietnamese conditions.

Tran, K. D., \& Nguyen, N.L.V., (2011). The scale for motivating employees. Journal of Economic Development, 244, 56-61.

Vroom, V.H. (1964). Work and Motivation. John Wiley, New York, NY, USA.

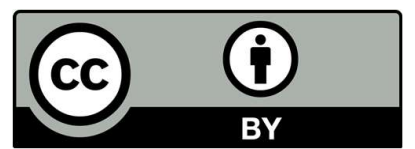

(C) 2020 by the authors; licensee Growing Science, Canada. This is an open access article distributed under the terms and conditions of the Creative Commons Attribution (CC-BY) license (http://creativecommons.org/licenses/by/4.0/). 